. кеев, . . р бч к, . . рофименко, . . ушк рев

ст тье исследуется влияние постоянного бокового и продольного ветр н ктивном уи стке тр ектории, $m$ кже влияние перекрестного ветр н полет неупр вляемых оперенных ре ктивных сн рядов. ссм трив ются особенности влияния постоянного ветр н полет турборе ктивного сн ряд н ктивном уч стке тр ектории. редложены м тем тические з висимости, позволяющие отдельно учесть боковое и продольное, прямое и перекрестное влияние ветр н ктивном уч стке тр ектории, полет неупр вляемых оперенных и вр щ, ющихс я ре ктивных сн рядов, $m$ кже учесть влияние ветр н $n$ ссивном уч стке тр ектории их полет .

лючевые слов: ктивный и п ссивный уч сток тр ектории, оперенные и вр щ, ющиеся ре ктивные сн ряды, эродин мические силы и моменты, боковой и продольн ый, прямой и перекрестный ветер.

\title{
RESEARCH OF INFLUENCING OF WIND ON FLIGHT OF THE NON-CONTROLLED WINGED JE T PROJECTILES AND REVOLVING JET PROJECTILES
}

\section{I. Makeyev, V. I. Grabchak, P. E. Trophimenko, Y. I. Pushkaryov}

The influence of permanent lateral and lo ngitudinal wind on the active area of trajectory is explored in the article, and cross wind influence on flight of the non-controlled winged jet projectiles. The features of influence of permanent wind on flight of turbojet projectiles on the active area of trajectory are examined. There are offered mathematical dependences which allow to consider separately lateral and longitudinal, direct and cross influence of wind on the active area of trajectory of flight of the non-controlled winged projectiles and revolving projectiles, and also to consider influence of wind on the passive area of trajectory of their flight.

Keywords: active and passive area of trajectories, winged jet projectiles and revolving jet projectiles, aerodynamic forces and moments, lateral and longitudinal wind, direct and cross wind.

\subsection{7}

. . ер симов, . . одорожняк, . . рібилєв

рківський університет овітряних илімені в н ожедуб, рків

ст тті розгляд еться спосіб підвищення ефекти вності використ ння, підвищення живучості р кетного озброєння 3 р хунок удоскон лення системи технічного контролю $m$ ді гностув ння рухомих пускових уст новок. пропонов ні три способи підвищення контролеприд тності втомобільного тяг ч - бзи рухомої пускової уст новки. озроблен методик вибору контрольов них $n$ р метрів втомобільного тягч, як вр ховуе особливості з пропонов них способів підвищення контролеприд тності. формульов ні з д чі оптиміз ції витр $m$ при контролі $m$ ді гностув нні втомобільного тяг ч , які є основою методики.

лючові слов : контрольов ні $n$ р метри, контролеприд тність, систем технічного контролю $m$ ді гностув ння.

\section{ступ}

ост новк проблеми. едення бойових дій із 3 стосув нням суч сної зброї вим г Є швидкого м неврув ння військ, їх швидкого зосередження, перегрупув ння для успішного проведення опер цій, тому удоскон лення системи технічного з безпечення рухомої пускової уст новки ( ) для p кетних, зенітних $p$ кетних комплексів $\epsilon$ кту льною 3 д чею [1]. сновною особливіст ю рухомого (мобільного) р кетного комплексу є те, що місце пуску р кети може бути змінено у визн чених меж х. зв'язку 3 цим виник $є$ можливість створення для супротивник невизн ченості в зн нні місця розт шув ння пускових уст новок із р кет ми н момент 3 вд ння ним уд ру по р йону 6 зув ння і з безпечення тим с мим умов для підвищення скритості комплексів.

н ліз літер тури. н ліз літер тури пок 3 в, що перспективним н прямком створення створення пускових уст новок н б зі втомобільного тяг ч $[2,3]$.

ехнічне обслуговув ння ( ) т ді гностув ння втомобільного тяг ч $\mathrm{T}$ його окремих грег тів спрямов но в цілому н вирішення одного чи декількох з вд нь: н визн чення технічного ст ну (спр вний чи неспр вний), пошук і лок ліз цію місця відмовлення чи неспр вності; н прогнозув ння з лишкового ресурсу імовірності

(․ . . ер симов, . . одорожняк, . . рібилєв 
безвідмовної роботи н інтерв л х н робітку, що 3 д ються, бо пробігу.

ідвищити коефіцієнт готовності втомобільного п рку можн 3 р хунок збільшення обсягу контрольно-ді гностичних робіт під ч с i ремонту. ля б г тьох втомобілів він перевищує 25-30 \% з г льного обсягу робіт із і ремонту. к пр вило, ч с, який витр ч ється н проведення вимірюв ння п р метрів, що дозволяють визн чити технічний ст н, у середньому дорівнює 5-10\% з г льного ч су ді гностув ння, інші 90-95\% доводиться н уст новку і зняття д тчиків, н вибір потрібного режиму роботи втомобіля й обробку результ тів ді гностув ння [3-5]. е вк зує н великий резерв у ч стині зниження трудом істкості

і ремонту втомобілів, що у першу чергу може бути ре лізов ний підвищенням контроле прид тності (пристосов ності втомобільного тяг ч до ді гностув ння).

ет ст тті поляг $€$ в розробці методики вибору контрольов них п р метрів рухомої пускової уст новки для р кетних $\mathrm{i}$ зенітних p кетних комплексів.

\section{сновний м тері л}

онтролеприд тність втомобільного тяг ч т його грег тів з безпечується н ст діях розробки i виготовлення дотрим нням вимог до технічного ді гностув ння в ч стині конструктивного викон ння виробів, п р метрів і методів ді гностув ння, пок зників оцінки контроле прид тності об'єКт [6].

онтролеприд тність втомобілів може бути підвищен одним із н ступних способів:

) $з$ р хунок зручного і простого підключення д тчиків до втомобіля, вибором н йбільш ефективних методів ді гностув ння і контролю, з безпеченням втомобіля універс льними, спеці льно передб ченими приєднув льними роз'єм ми, штуцер ми, з глушк ми і т.д.;

б) введенням у конструкцію втомобіля вбудов них д тчиків, до вив одів яких н період ді гностув ння можн підключ ти зовнішні з соби вимірюв ння т ді гностув ння;

в) комплектув нням втомобілів бортовими систем ми контролю, що вид ють водію у будьякий момент ч су інформ цію про технічний ст н відповідного вузл , систе ми грег ту.

пр ктиці н йбільш доцільно комплексне використ ння всіх трьох перер хов них способів підвищення контролеприд тності втомобілів. озробимо методики вибору контрольов них п р метрів втомобільного тяг ч для кожного способу підвищення контролеприд тності.

оменкл туру структурних і ді гностичних п р метрів і іхні норм тивні зн чення ( . . ер симов, . . одорожняк, . . рібилєв вст новлюють 3 обліком конструктивних, технологічних і експлу т ційних ф кторів. имоги до технічного ді гностув ння втомобільних тяг чів включ ють н розробку й освоєння нових тяг чів, у т ктико-технічне з вд ння н їхню розробку, в ст нд рти н технічні умови, у з г льні технічні умови т конструкторську документ цію н тяг ч.

ибір контрольов них п р метрів втомобіль ного тяг ч $є$ одним із н йбільш в жливих н уковометодичних пит нь орг ніз ції $\mathrm{T}$ розвитку технічного з безпечення $\mathrm{p}$ кетного, зенітного р кетного озброєння, від рішення якого зн чн ою мірою 3 лежить ефективність функціонув ння 3 зн чених систем озброєння.

p диційно вибір контрольов них п р метрів для оцінки технічного ст ну втомобільних тяг чів здійснюють $з$ номенкл тури, що рекомендується держ вними ст нд рт ми й іншою норм тивнотехнічною документ цією.

ьогодні втомобільні тяг чі можуть осн щув тись бортовими і вбудов ними систем ми контролю, при цьому не втр ч ють кту льність і тр диційні системи зовнішнього контролю т ді гностув ння. Зв'язку з цим при виборі контрольов них п р метрів необхідно визн чити, які 3 них доцільно контролюв ти бортовими систем ми, які - 3 допомогою зовнішніх з собів технічного контролю т ді гностув ння.

озглянуте 3 вд ння може бути вирішено 3 допомогою методики, як 3 снов н н критерії економічності контролю п р метрів втомобільного тяг ч [7]. пропонов н методик передб ч є три можливих методи контролю: 3 допомогою зовнішніх тр диційних з собів, систем вбудов них д тчиків ( ) і бортових систем контролю. ля методів контролю т ді гностув ння 3 допомогою зовнішніх тр диційних з собів і скл д ються цільові функції, що х р ктеризують з лежність витр т від періодичності ді гностув ння розглянутого елемент тяг ч . інімум цих функцій i д $\epsilon$ оптим льну періодичність контролю т ді гностув ння, що визн ч $є$ мінім льні витр ти н експлу т цію і ремонт елемент, включ ючи й витр ти н контроль і ді гностув ння. ля третього методу ді гностув ння т кож 3 пропонов Н формул визн чення витр т.

рипустимо, що при виборі контрольов них п р метрів з стосовується метод, сутність якого поляг $€$ в н ступному. ибир ють основні структурні п р метри ${ }_{i}, \quad$ які можуть використовув тись як контрольов ні, і п р метри $j$, які можн використовув ти в якості ді гностичних. д ними ст тистики відмовлень визн ч ють «вплив» структурних п р метрів н 
можливість викон ння (невикон ння) об' єктом своїх функцій, $\quad$ т кож вст новлюють імовірність невизн чення неспр вного ст ну тяг ч 3 результ т ми контролю п р метрів (при різних комбін ціях п р метрів) т імовірність помилкового визн чення спр вного тяг ч неспр вним.

етодик вибору контрольов них п р метрів втомобільного тяг ч скл д єТься у викон нні н ступної послідовності опер цій.

1. основі експеримент льних досліджень, вивчення н уково-технічної літер тури, технічної й експлу т ційної документ ції $\mathrm{H}$ втомобільний тяг ч $з$ д ти н ступні вихідні д ні: 1- витр ти н проведення одного контролю; - припустимі витp ти н проведення одного контролю; і - відповідно витр ти н профіл ктичний і в рій ний ремонти елемент ; $\quad$ i — відповідно припустимі витр ти н профіл ктичний і в рійний ремонти елемент ; $D$ - питомий чистий прибуток, який д є тяг ч 31 годину експлу т ції (величин зворотно пропорційн збитк м, які будуть отрим ні при використ нні неспр вного тяг ч ); $P_{C}(\tau)$ - імовірність того, що тяг ч пройде профіл ктичний ремонт після пробігу $\tau ; P_{A}(\tau)$ - ймовірність того, що тяг ч не пройде в рійний ремонт після пробігу $\tau$; $\mathrm{t}_{1}-$ ч с проведення вимірюв ння одного п р метр ;

$t \quad-$ допустимий $\quad$ ч $\mathrm{c} \quad \mathrm{H} \quad$ проведення вимірюв ння одного п р метр ; $t$ i $t$ - відповідно ч с, відведений н профіл ктичний і в рійний ремонти елемент ; $t$ і $t \quad-$ відповідно припустимий ч с, відведений н профіл ктичний і в рійний ремонти елемент ; 2- витр ти н одне ді гностув ння при використ нні ; 2 припустимі витр ти н одне ді гностув ння при використ нні $; t_{2}-$ ч с н ді гностув ння елемент при ; $t_{2}-$ припустимий ч с н ді гностув ння елемент при ; відповідно витр ти н і термін служби розглянутого елемент ; відповідно припустимі зн чення витр т н терміну служби розглянутого елемент ; термін служби системи бортового контролю ( ); - припустимий термін служби; витр ти (в ртість) ; - витр ти н ремонт і (стосовно до розглянутого елемент ) 3 термін її служби; - припустимі витр ти н ремонт і (стосовно до розглянутого елемент ) з термін їі служби; - контрольов ні ч стини втомобіля, для яких буде зроблений профіл ктичний ремонт н кожну тис. км пробігу.

2. ирішити з д чі оптиміз ції витр т н ді гностув ння і контроль елемент для розглянутих методів, його ремонти і простої в ремонт $\mathrm{x}$ :

) цільов функція витр т н контроль елемент першим методом, його ремонти і простої у ремонт $\mathrm{x}$ у з лежності від періодичності контролю н тис. км пробігу м є вигляд [7]

$$
\begin{aligned}
& C_{1}(\tau)=\tau^{-1}\left\{B_{1}+C P_{C}(\tau)+A P_{A}(\tau)+\right. \\
& \left.+D\left[t_{B 1}+t_{C} P_{C}(\tau)+t_{A} P_{C}(\tau)\right]\right\} .
\end{aligned}
$$

ля вирішення 3 д чі оптиміз ції витр т $\mathrm{H}$ ді гностув ння і контроль елемент 3 допомогою першого методу необхідно визн чити мінімум цільової функції $C_{l}(\tau) \quad 3 \quad$ ур хув нням 3 д них обмежень, тобто

$$
1=\min C_{1}(\tau) \text {, }
$$

при н ступних обмеженнях:

$$
\begin{aligned}
& 1<\quad \text {; } \\
& <\quad \text {; } \\
& <\quad \text {; } \\
& t_{1}<t_{1} \text {; } \\
& t<t \text {; } \\
& t<t
\end{aligned}
$$

б) цільов функція при другому методі контролю м є вигляд

$$
\begin{aligned}
& C_{2}(\tau)=\tau^{-1}\left\{B_{2}+C P_{C}(\tau)+A P_{A}(\tau)+\right. \\
& \left.+D\left[t_{B 2}+t_{C} P_{C}(\tau)+t_{A} P_{C}(\tau)\right]\right\}+\tau C
\end{aligned}
$$

ля вирішення 3 д чі оптиміз ції витр т н ді гностув ння і контроль елемент 3 допомогою другого методу необхідно визн чити мінімум цільової функції $C_{2}(\tau)$ з ур хув нням 3 д них обмежень, тобто

$$
2=\min C_{2}(\tau),
$$

при н ступних обмеженнях:

$$
\begin{aligned}
& 2<2 \text {; } \\
& t_{2}<t_{2} \text {; } \\
& <\quad \text {; } \\
& <
\end{aligned}
$$

в) витр ти, що відповід ють третьому методу контролю, визн ч ють 3 формулою

$$
C_{3}(\tau)=T^{-1}(+)+P+D t_{C} P .
$$

ля рішення 3 д чі оптиміз ції витр т $\mathrm{H}$ ді гностув ння і контроль елемент 3 допомогою третього методу необхідно зн йти мінімум цільової функції $C_{3}(\tau)$ з ур хув нням 3 д них обмежень, тобто $\quad{ }_{3}^{*}=\min C_{3}$, при н ступних обмеженнях: 


$\begin{array}{ll}< & \quad ; \\ < & \end{array}$

інімум із трьох н ведених чисел $C_{1}, C_{2}, C_{3}^{*}$, розр хов них з формул ми (1) - (3), ук зує н н йбільш доцільний метод кон тролю.

ля визн чення скл дових $P_{A}(\tau), P_{C}(\tau), P_{B}(\tau)$ необхідно зн ти з лежність імовірності безвідмовної роботи елемент $Q(\tau)$ з пробіг $\tau$ тяг ч . йч стіше це функція

$$
Q(\tau)=1-i^{-\lambda \tau},
$$

де $\lambda-\Pi$ р метр функції.

ким чином, з пропонов н методик дозволяє визн чити оптим льний метод контролю т ді гностув ння втомобіля при 3 д ному методі вибору його контрольов них п р метрів.

\section{ИСНоВ К И}

ри орг ніз ції технологічного процесу контролю т ді гностув ння ст виться 3 д ч р ціон льної мініміз ції числ контрольно вимірюв льних опер цій, підвищення точності вимірюв нь ді гностичних п р метрів і відповідно вірогідності пост новки ді гнозу. ри цьому повинн дотримув тися 3 г льн умов мініміз ції витр т н експлу т цію, обслуговув ння i ремонт об'єкт, який ді гностується, зі збереженням н н лежному рівні коефіцієнт готовності озброєння. лгоритм ді гностув ння будується т ким чином, щоб 3 обр ним переліком п р метрів і послідовності їхніх вимірюв нь визн чити пр цезд тність об’єкт і лок лізув ти виявлені при цьому неспр вності. либин лок ліз ції неспр вності визн ч ється в кожн ому конкретному вип дку своїм рівнем: $з$ міною дет лі, чи ремонтом вузл грег ту, проведенням якихось регулюв льних робіт. ей рівень визн ч ється експлу т ційними й економічними ф ктор ми, нормов ними пок 3ник ми н дійності, вимог ми з безпечення безпеки дорожнього руху, збереження екологічних х р ктеристик i т. д. озроблен методик дозволяє визн чити оптим льний перелік п р метрів втомобільного тяг ч для контролю т ді гностув ння, що дозволить підвищити ефективність експлу т ції озброєння при незн чних витр т х.

\section{писок літер тури}

1. ехнические основы эффективности $p$ кетных систем / [ . . олков, . . воркин, . . рокудин и др.]. одред. . . олков . - .: шиностроение, 1990. $-256 c$

2. ехническ я эксплу $m$ ция втомобилей / одред. . . узнецов . - .. p нспорт, 1991. - 413 c.

3. $p$ зов. . и гностическое обеспечение технического обслужив ния и ремонт втомобилей / . . $р$ зов. - .. ысш я школ , 1990. - 208 с.

4. етрологическое обеспечение и эксплу $m$ иия измерительной техники/ [ . . огд нов, . . узнецов, . . отонов и др.]; под ред. . . узнецов . - . дио и связь, 1990. - 240 c.

5. овременные м тем тические методы н лиз и синтез сложных систем / од ред. . . л женков .$\therefore \quad$, 1984. -382 c.

6. еляев . . дежность технических систем: пр вочник / еляев . ., ог тырев . ., окотин . . од ред. . . ш ков . - .. дио и связь, 1985. - $606 \mathrm{c}$.

7. уев. . ехнические з дчи исследов ния опер ций / . . уев, . . пехов . .. ов. р дио, 1971. $-344 c$.

дійщл до ред кції 10.12.2008

ецензент: доктор технічних н ук, професор отніков, рківський університет овітряних ил імені в н ожедуб, рків.

\section{. . ер симов, . . одорожняк, . . рибылев}

ст тье р ссм трив ется способ повышения эффективности использов ния, повышения жсивучести р кетного вооружения з счет совершенствов ния системы технического контроля и ди гностики подвижных пусковых уст новок. редл г ются три способ повышения контролепригодности втомобильного тяг ч - б зы подвижной пусковой уст новки. зр бот н методик выбор контролируемых $n$ р метров втомобильного тяг ч, котор я учитыв ет особенности предл г емых способов повышения контролепригодности. формулиров ны з д чи оптимиз ции з тр т при контроле и ди гностике втомобильного тяг ч, котор я является основой мет одики.

лючевые слов: контролируемые $n$ р метры, контролепригодность, систем технического контроля и ди гностики.

\section{DEVELOPMENT OF METHOD OF CHOICE OF THE CONTROLLED PARAMETERS} OF MOBILE LAUNCHER

\section{S. V. Gerasimov, A. A. Podorozhnyak, Y. B. Pribylev}

In the article the analysis of increase in efficiency of the use, increase in survivability of rocket armament due to perfection of the technical checking and diagnostics of launchers is presented. Three methods of increase of control measuring of motor -car tractor - base of the mobile launcher are offered. The method of choice of the controlled parameters of motor-car tractor is developed, which takes into account the features of the offered methods of increase of control measuring. The tasks of optimization of expenses at control and diagnostics of motor-car tractor, which forms the basis of method, are formulated.

Keywords: controlled parameters, control measuring, technical checking and diagnostics system.

( . . ер симов, . . одорожняк, . . рібилєв 